\title{
Moderating Effect of Interest Rates on Relationship between Foreign Exchange Rate Fluctuation and Performance of Nairobi Securities Exchange Market
}

\author{
Johnmark Obura ${ }^{1, *}$, Cynthia Anyango ${ }^{2}$ \\ ${ }^{1}$ Department of Management Science, Maseno University, Kenya \\ ${ }^{2}$ Department of Statistics, Maseno University, Kenya
}

Copyright $\bigcirc 2015$ by authors, all rights reserved. Authors agree that this article remains permanently open access under the terms of the Creative Commons Attribution License 4.0 International License

\begin{abstract}
Performance of Nairobi Securities Exchange (NSE) market has remained unpredictable. This could have led to past investor losses. If this situation continues, it could lead to continued loss of investor confidence in NSE market. However, literature links foreign exchange rates fluctuation and interest rates with NSE performance. In Kenya, exchange market is active. Further, stable interest rates attract investors. Despite this, exchange rates fluctuation and interest rates have not been considered as influencing securities market performance. Moreover, reviewed literatures have left theory building impoverished due to contradiction. The study attributed this to possible moderation of the relationship between foreign exchange rates fluctuation and securities market performance by interest rates. The study sought to determine the moderating effect of interest rates on the relationship. Corelational design on secondary data between January, 2006 and December, 2010 was utilized. Hierarchical regression established significant change in $\mathrm{R}^{2}$ of 0.085 confirming moderation. The study concludes that interest rates moderate the relationship and recommends that policies governing the regulations of interest rates should be formulated since it moderates the relationship. Future researchers can adopt other techniques in the same area of study. In advancing a model and revealing moderation the study contributes to theory building.
\end{abstract}

Keywords Performance, Exchange Rates, Interest Rates, Securities Market, Fluctuation

\section{Introduction}

\subsection{Background of the Study}

Economists have traditionally concentrated on the role of financial development to the economic growth of countries. Overall, there exists an overwhelming consensus that well functioning financial intermediaries have played a significant role in economic growth [11,12,16-18,30]. More recently, the emphasis has been increasingly shifted to stock market indicators and the effect of stock markets on economic development and the latter has been the subject of recent theoretical interest $[6,16]$. Although some analysts view stock markets in developing countries as "casinos" that have little positive impact on economic growth, recent evidence suggests that stock markets may give a big boost to economic development. In fact, the focus on stock markets as an engine of economic growth is a new opening in financial literature. Going further, its benefits had been largely ignored in the past, but now there is consensus concerning the positive effects brought about by stock markets [16]. Performance of Securities market and its improvement has been the focus of almost all financial market studies [1]. Given the ever growing interest to invest in the securities markets with ever fluctuating security prices, and since there exists some level of fluctuation in the foreign exchange rate and interest rates, the researcher found it necessary to compare the activities of the two markets and determine if interest rates moderates their relationship. The objective of the study was therefore to determine the moderating effect of interest rates on relationship between foreign exchange rate fluctuation and the performance of Nairobi Securities Exchange market.

The study makes two major contributions to existing knowledge. First, whereas most of the studies reviewed concentrated on using pure econometric models in studying stock markets and causation, the current study employed the 2 -step least squares model, which yielded an equation that could be used to predict change in price index in stock markets whenever fluctuation in major currencies were observed. Second, none of the studies reviewed explored the 
influence of interest rates when studying foreign exchange fluctuation and performance of the stock markets. The current study therefore revealed that interest rates could be incorporated in studies relating to stock markets as moderating variables.

\subsubsection{Foreign Exchange Rates Fluctuation}

Exchange rate is the price of one country's currency expressed in another country's currency. In other words, it is the rate at which one currency can be exchanged for another. It is the process of trading the currency of one country for the currency of another. This process is necessary for international trade to take place in a world of different currencies. Exchange rate is a national and international political, social and economic indicator. In developed countries, it reacts quickly to events like war, terrorism, and also to the changes in the political situation as well as to main economic indicators like unemployment and interest rate. From a macro perspective, foreign exchange rate has an effect on the country's economy whereas from a micro perspective it affects the firms, [21]. The foreign exchange market is the largest and oldest financial market in the world. The value of one currency versus another is determined by the international exchange rate and, in most cases, is subject to fluctuation based on open trading of currency in foreign exchange markets, [14]. The market for foreign exchange involves the purchase and sale of national currencies. A foreign exchange market exists because economies employ national currencies. If the world economy used a single currency there would be no need for foreign exchange markets. In Europe for example, more than eleven economies have chosen to trade their individual currencies for a common currency. But the Euro will still trade against other world currencies. For now, the foreign exchange market is a fact of life [5].

\subsubsection{Interest Rates}

Traditional theories define interest rate as the price of savings determined by demand and supply of loanable funds. It is the rate at which savings are equal to investment assuming the existence of a capital market. The loanable fund theory argues that interest rate is determined by non-monetary factors. It assigns no role to quantity of money or level of income on savings, or to institutional factors such as commercial banks and the government. The liquidity theory, on the other hand, looks at the interest rate as the token paid for abstinence and inconveniences experienced for having to part with an asset whose liquidity is very high. It is a price that equilibrates the desire to hold wealth in the form of cash with the available quantity of cash, and not a reward of savings. Interest rate is a function of income. Its primary role is to help mobilize financial resources and ensure the efficient utilization of resources in the promotion of economic growth and development [24].An interest rate is the rate charged or paid for using money. You are charged an interest rate when you borrow money and paid an interest rate when you loan money (placing it in a savings or investment account is like a loan to the bank).

Both the lending rates and deposit rates will be considered as the main dimensions of interest rates in the present study

\subsubsection{Performance of Securities Market}

The financial reform process emphasizes the development of the securities market as an alternative source of long-term capital in emerging markets. Long-term capital is crucial for economic development given the positive relationship between long-term capital and economic growth [7]. As a priority therefore, the Kenya government in the 1997/2001 Development Plan noted the need to shift from the expensive short-term finance in favor of cheaper long-term finance for sustainable industrialization to be achieved. The need for long-term capital to finance private investment is not a recent realization in Kenya. As far back as the 1920s, foreigners who dominated the economic activities initiated share trading. Then, at independence, the government set up Development Financial Institutions (DFIs) to close the resource gap for long-term capital, [2].

Establishment of the capital market regulator and diversification of the money market instruments was also recommended to oversee the development of the capital market and strengthen surveillance of market activities. Consequently, the Capital Market Authority (CMA) was established in1990, marking a shift from the self-regulatory system to the statutory regulatory system. Further, the securities exchange has in the recent period been lobbying the government to create conducive policy environment to facilitate growth of the economy and the private sector to enhance growth of the stock market. In addition, the divestiture of government parastatals through the securities market is expected to promote growth of the securities market [23].

Despite the long history and efforts made to revitalize the securities market, growth of the primary market is still very slow. For example, the number of listed firms presently is similar to the number of firms listed at independence and at the beginning of the reform process. Further, the number of traded securities in the market is very minimal, therefore narrowing diversity in sourcing for funds. The 1974/78Development Plan the government admitted that the financial sector was not playing its role effectively in the development process [25].

\subsubsection{Performance of Nairobi Securities Exchange Market}

The performance of Nairobi Securities Exchange market continues to remain unpredictable such as the case observed in February 2006 when there was a rise in the index to 4057 , further to 5774 in January 2007 and to as low as 2475 in February, 2009 [8]. This could have led to past losses incurred by investors in Kenya as witnessed during the period January to June 2009 when the market was bearish leading to the collapse of a number of brokerage and investment firms leaving investors in total despair. If this undesirable situation is not addressed, it could lead to continued loss of investor confidence in Nairobi Securities 
exchange market which has been hailed as one of the leading securities market in Africa. However literature links foreign exchange rates fluctuation and interest rates with the performance of securities markets. In Kenya Foreign Exchange market is active, a situation which is expected to remain the same due to globalization of the economy and increased cross border transactions. For example, the value of total exports from Kenya increased by $25.6 \%$ between 2007 and 2008 and that of imports to Kenya increased by $27.4 \%$ during the same period [8]. To add, favorable and stable interest rates are considered to attract both local and foreign investors who may be willing to either deposit their funds as saving with the hope of earning additional money or borrow funds from financial institutions and put into investment like purchase of shares from securities market oblivious of the risks involved. It is clear that literature links foreign exchange rates fluctuation with the performance of Securities markets. In Kenya Foreign Exchange market is active, a situation which is expected to remain the same due to globalization of the economy. Despite this situation, foreign exchange rates fluctuation and interest rates have hitherto not been considered as factors influencing performance of Nairobi Securities exchange market. Moreover, literature linking the two has left theory building impoverished because of contradictory results such as: $[1,3$, $4,13,20,26,34,35]$.

\section{Literature Review}

\subsection{Empirical Review on Foreign Exchange Rates Fluctuation and Performance of Securities Market}

The study by Golaka and Samanta [9] on relationship between exchange rate and stock prices in India examined the causal relationship between returns in stock market and forex market in India. Using daily data from March 1993 to December 2002, they found that causal link is generally absent though in recent years there has been strong causal influence from stock market return to forex market return. They recommended further in-depth research to identify the causes and consequences of their findings. The current study therefore intended to analyze the relationship between foreign exchange rates and performance Nairobi securities market while introducing interest rates as moderating the relationship.

In Ghana, [3] studied the relationship between Stock Markets and Foreign Exchange market to determine whether movements in exchange rates have an effect on stock market in Ghana. The Exponential Generalised Autoregressive Conditional Heteroskedascity (EGARCH) model was used in establishing the relationship between exchange rate volatility and stock market volatility. It was found that there is negative relationship between exchange rate volatility and stock market returns - a depreciation in the local currency leads to an increase in stock market returns in the long run.
Where as in the short run it reduces stock market returns. Additionally, there is volatility persistence in most of the macroeconomic variables; current period's rate has an effect on forecast variance of future rate. It was also revealed that an increase (decrease) in trade deficit and expectation in future rise in trade deficit will decrease (increase) stock market volatility. In addition, the consumer price index has a strong relationship with stock market volatility. This means that an increase in consumer price will lead to a rise in stock market volatility. Finally, there existed leverage effect and volatility shocks in stock returns on the Ghana Stock Exchange.

In Nigeria [13], through the Error Correction model investigated the effects of exchange rate volatility on the Nigeria stock markets. It was found that the exchange rate volatility generated via GARCH process exerts a stronger negative impact on the Nigeria stock markets. However the rate of inflation and interest rate did not have long run relationship with stock market capitalization since the major participant in the market is government. Based on this it is recommended that a coordinated monetary and fiscal policy should be put in place to check mate the fluctuation of exchange rate in order to deepen the depth of the Stock Market.

In Turkey, Tulin [34] explored the relationship between changes in foreign exchange rates (Euro/TRY, GBP/TRY, JPY/TRY, CHF/TRY, USD/TRY, CAD/TRY, SA/TRY) and the main composite index at Istanbul Stock Exchange by employing monthly data spanning from January 1999 and November 2011. Based on the Augmented Dickey Fuller and other techniques of time series analysis he found that all variables in the estimation framework are non-stationary at the initial level; the stationarity was achieved at a first difference level. His results indicated that changes in domestic U.S. Dollar and Canadian dollar are positively related to changes in ISE 100 while fluctuation in domestic interest rates and Saudi Arabia Riyal has a negative impact on the index.

\subsection{Empirical Review on Interest Rates and Performance of Securities Market}

The study by Jyoti and Alain [10] examined the relationship between the interest rate, exchange rate and stock price in the Jakarta stock exchange. The study was conducted for a five year period from 1993 to 1997 which was divided into three sub periods. Depending on the sub periods being considered, sporadic unidirectional causality from closing stock prices to interest rates and vice versa and weak unidirectional causality from exchange rate to stock price were found. The overall evidence, however, failed to establish any consistent causality relationships between any of the economic variables under study. Hence it seems that Jakarta market efficiently incorporated much of the interest rate and exchange rate information in its price changes at closing stock market index. These results can be used as a 
measure of stock market efficiency, however with caution, as there are many other dimensions that have to be studied before arriving at any definite conclusion about the efficiency.

The study of Pallegedara and Asankha [26] examined the dynamic relationships between stock market performance and the interest rates in Sri Lanka during June 2004 to April 2011. They used all share price index in the Colombo stock exchange as a measure of stock market performance indicator and Sri Lanka interbank offer rate as a measure of interest rate. They employed some conventional time series econometric techniques namely Unit root test, cointegration test, vector auto correction model (VECM), Granger-Causality test and Impulse response functions (IRF) to trace out the relationships between stock market index and interest rate. The findings were that stock market performance was negatively associated with interest rate in the long run while no causal relationship was found in the short run.

The study of Naliniprava and Meghalaya [22] investigated the market efficiency and causal relationship between selected Macroeconomic variables and the Indian stock market during the period January 2005 to February 2011 by using Ljung-Box Q test, Breusch-Godfrey LM test, Unit Root test, Granger Causality test. The study confirmed the presence of autocorrelation in the Indian stock market and macro-economic variables which implied that the market fell into form of Efficient Market Hypothesis. Further the Granger-causality test showed evidence of bidirectional relationship between interest rate and stock market, exchange rate and stock market, international stock market and BSE volume, exchange rate and BSE volume. So it suggested that any change of exchange rate, interest rate and international market significantly influencing the stock market in the economy and vice versa. The study also reported unidirectional causality running from international stock market to domestic stock market, interest rate, exchange rate and inflation rate indicating sizeable influence in the stock market movement in the considered period. The study points out that the Indian stock market is sensitive towards changing behavior of international market, exchange rate and interest rate in the economy and they can be used to predict stock market price fluctuation.

\section{Research Methodology}

\subsection{Research Design}

Research design began with selection of the topic and a paradigm, [29] the topic of the research was to analyzes the effect of foreign exchange rates fluctuation, interest rates on the performance of Nairobi Securities Exchange market. A paradigm provided the research with an idea of assumptions about the social world and how a study should be conducted. It also encompasses both theories and methods. According to
Philips [27] and Creswell [6], a study can follow a qualitative and/or quantitative paradigm. This study followed a quantitative paradigm which is termed experimental and empiricist, Schiffman and Kanuk, [31] as it was in tandem with the researcher's characteristics in terms of training and experience and the main purpose of the study, Creswell [6].The study adopted a correlational case study design. The research attempted to determine and explain the relationship between the variables of the two markets based on systematic comparison aimed at discovering inferences or causal relationships.

\subsection{Data and Data Collection}

Secondary data was utilized in the study. The data on foreign exchange rates, interest rates and performance of Nairobi Securities Exchange market, measured in this case by NSE 20 share index, for the period covering January, 2006 and December, 2010were obtained mainly through document reviews. This comprised of monthly data on the NSE-20 share index, time deposit and lending rates and the following foreign exchange rates:

EURO/KShs: 1 Euro /Kenya Shillings

POUND/KShs: 1 British Pound / Kenya Shillings

DOLLAR/KShs: 1 US Dollar / Kenya Shillings

\subsection{Data Analysis}

Regression analysis was employed. Because multiple regression analysis was used to test the effects of foreign exchange rates fluctuation on performance of the Nairobi securities exchange market, the validity of the assumptions of multiple regression analysis in the case of time series data were first checked. The Durbin-Watson test was used to check for autocorrelation, Dickey-Fuller tests were used to test for non-stationarity, and Johansen's test was used to test for cointegration, Variance inflation factors (VIF) were used to test for multicollinearity and Breusch-Pagan test was used to test for heteroskedasticity.

\subsubsection{Testing for Non-stationarity}

The time series trends indicated that all the variables used in the study had unit root in them and hence were non-stationary. Formal investigation for non-stationarity was therefore done through application of Augmented Dickey Fuller (ADF) test. The ADF tested the null hypothesis of unit root in the series. Upon performing the test, the test statistics were compared to the critical values. If the ADF statistics exceeded the critical value, the null hypothesis of unit root in the series was rejected. Otherwise it was accepted.

Table 1 reports the results of Augmented Dickey Fuller test of unit root. The test was applied at level as well as in the first difference.

From Table 1, ADF statistics reported that all the variables under consideration contained unit root at level, as ADF statistics did not exceed $1 \%$ as well as $5 \%$ critical values i.e. they were all non-stationary at level. They however became stationary in first difference. 
Table 1. Results of Unit Root investigation (ADF Test)

\begin{tabular}{|c|c|c|c|c|}
\hline Variable & ADF Test & Test Statistic & $1 \%$ Critical value & $5 \%$ Critical value \\
\hline \multirow{2}{*}{$\begin{array}{c}\text { Average Deposit } \\
\text { Rate }\end{array}$} & At Levels & -1.197500 & -3.546099 & -2.911730 \\
\cline { 2 - 5 } & First Difference & -7.172085 & -3.548208 & -2.912631 \\
\hline \multirow{2}{*}{$\begin{array}{c}\text { Rverage Lending } \\
\text { Rate }\end{array}$} & At Levels & -1.762984 & -3.546099 & -2.911730 \\
\cline { 2 - 5 } Euro & First Difference & -7.148833 & -3.548208 & -2.912631 \\
\cline { 2 - 5 } & At Levels & -1.697450 & -3.546099 & -2.911730 \\
\hline \multirow{2}{*}{ Pound } & First Difference & -7.175227 & -3.548208 & -2.912631 \\
\cline { 2 - 5 } & At Levels & -1.991288 & -3.546099 & -2.911730 \\
\hline \multirow{2}{*}{ Us dollar } & First Difference & -7.430079 & -3.548208 & -2.912631 \\
\cline { 2 - 5 } & At Levels & -1.369108 & -3.546099 & -2.911730 \\
\hline \multirow{2}{*}{ Price Index } & First Difference & -5.750587 & -3.548208 & -2.912631 \\
\cline { 2 - 5 } & At Levels & -1.250266 & -3.546099 & -2.911730 \\
\hline
\end{tabular}

Source: Research data, 2013

\subsubsection{Johansen's Test for Co Integration}

Co-integration was used to determine the long run relationship between price index and foreign exchange rates on one hand and between price index and interest rates on the other. Johansen co integration technique was used and revealed results presented in Table 2

Table 2. Results of Johansen's Co integration Test

\begin{tabular}{|c|c|c|c|}
\hline Variable & Eigen Values & Trace Stat & $\begin{array}{c}5 \% \text { Critical } \\
\text { value }\end{array}$ \\
\hline $\begin{array}{c}\text { Average Deposit } \\
\text { Rate }\end{array}$ & 0.06923 & 4.3922 & 15.41 \\
\cline { 2 - 4 } & 0.00398 & 0.2313 & 3.76 \\
\hline \multirow{2}{*}{$\begin{array}{c}\text { Average Lending } \\
\text { Rate }\end{array}$} & 0.23164 & 16.4467 & 15.41 \\
\cline { 2 - 4 } & 0.01987 & 1.1641 & 3.76 \\
\hline \multirow{2}{*}{ Euro } & 0.16815 & 12.7083 & 15.41 \\
\cline { 2 - 4 } & 0.0302 & 2.0302 & 3.76 \\
\hline \multirow{2}{*}{ Pound } & 0.18839 & 13.7776 & 15.41 \\
\cline { 2 - 4 } & 0.02840 & 1.6713 & 3.76 \\
\hline \multirow{2}{*}{ US Dollar } & 0.05269 & 4.6049 & 15.41 \\
\cline { 2 - 4 } & 0.02840 & 1.4656 & 3.76 \\
\hline
\end{tabular}

Dependent Variable: Price Index

Source: Research data, 2013

Results indicated that the trace statistics (likelihood ratio) for the dollar, pound, Euro and average deposit rates did not exceed the $5 \%$ critical value. This implies that there was no co-integrating relation between price index and exchange rates. Consequently, price indices and exchange rates do not move together in the long run. This is consistent with findings by Lee [15] that short run linear causality exists between stock market and exchange rate but no long run relationships. Lack of co integration further supports views by Reilly [28] that unexpected changes in the rate of inflation make it difficult for firms to plan, which inhibits growth and innovations. Beyond the impact of the domestic economy, differential inflation and interest rate influence the trade balance between countries and exchange rate of currencies. Besides, they support the findings by Mendelson et al, [19], which indicated that events such as war, political upheavals within or outside a country, or international monetary devaluation produces changes in the business environment that lead to uncertainties and earnings expectations of investors therefore increasing the risk premium of investors.

The table however shows that there was co-integration between price index and average lending rate. These are consistent with the findings by Pallegedara and Asankha [26] showing that stock market performance was negatively associated with interest rate in the long run while no causal relationship was found in the short run.

\subsubsection{Testing for Multicollinearity}

Multicollinearity was examined by regressing each of the independent variables against all other independent variables. Table 3 presents the R-squared statistic and the variance inflation factor (VIF) for each equation.

Table 3. Multicollinearity Results for the Independent and Moderator Variables

\begin{tabular}{|c|c|c|}
\hline Variable & Auxiliary $\mathrm{R}^{2}$ & VIF \\
\hline Average Lending Rate & 0.142 & 1.166 \\
\hline Average Deposit Rate & 0.082 & 1.089 \\
\hline Euro & 0.396 & 1.656 \\
\hline Pound & 0.346 & 1.642 \\
\hline US dollar & 0.181 & 1.222 \\
\hline
\end{tabular}

Source: Research data, 2013

Based on the very small values of the $\mathrm{R}^{2}$ and the VIF for all the variables, the data was found to have no issues of multicollinearity.

\subsubsection{Testing for Autocorrelation}

The Durbin-Watson statistics were used to test for the presence of autocorrelation. Consequently, the null 
hypothesis that there was no autocorrelation was tested. A value of the Durbin-Watson statistic close to 2 was adjudged to indicate lack of serial correlation. Each variable was regressed against all the other variables in order to determine the Durbin-Watson statistic for each variable. Table 4 reveals that with the exception of the US dollar, all the other variables had no cases of autocorrelation.

Table 4. Results of Autocorrelation Test

\begin{tabular}{|c|c|c|}
\hline Variable & Durbin-Watson Stat & Conclusion \\
\hline $\begin{array}{c}\text { Average Lending } \\
\text { Rate }\end{array}$ & 2.084 & No autocorrelation \\
\hline $\begin{array}{c}\text { Average Deposit } \\
\text { Rate }\end{array}$ & 2.060 & No autocorrelation \\
\hline Euro & 2.055 & No autocorrelation \\
\hline Pound & 1.942 & No autocorrelation \\
\hline US dollar & 1.067 & $\begin{array}{c}\text { Some positive } \\
\text { autocorrelation }\end{array}$ \\
\hline
\end{tabular}

Source: Research data, 2013

Autocorrelation in the US dollar was considered to be minimal and thus the variable was retained but with this as a limitation in mind.

\subsubsection{Testing for Heteroskedasticity}

Data was also checked for constant variance in the error term. The null hypothesis for this test for each variable was that the variance was constant. A significant heteroskedasticity chi-square value would then indicate evidence of heteroskedasticity. Results are presented in Table 5 .

Table 5. Results of the Heteroskedasticity Test

\begin{tabular}{|c|c|c|}
\hline Variable & Chi2(1) & Prob >Chi2 \\
\hline $\begin{array}{c}\text { Average Lending } \\
\text { Rate }\end{array}$ & 0.07 & 0.7910 \\
\hline $\begin{array}{c}\text { Average Deposit } \\
\text { Rate }\end{array}$ & 0.01 & 0.9151 \\
\hline Euro & 13.71 & 0.0002 \\
\hline Pound & 0.81 & 0.3691 \\
\hline US dollar & 0.11 & 0.7438 \\
\hline Price Index & 0.23 & 0.6330 \\
\hline
\end{tabular}

Source: Research data, 2013

Results presented in Table 5 reveal that the chi2 (1) statistics for average lending rate, average deposit rate, pound, US dollar and price index were not significant. This implies that these variables had no heteroskedasticity. The chi2 (1) statistic for the Euro was found to be significant indicating presence of heteroskedasticity. Once again, the variable was retained under this limitation.

\section{Results and Discussions}

\subsection{Model Specification}

The study conceptualized that performance of the securities market could be influenced by both average lending rates and average deposit rate.

Consequently, the following moderation model was estimated:

$$
\mathrm{Y}=\beta_{0}+\beta_{1} \mathrm{X}+\beta_{2} \mathrm{M}+\beta_{3} \mathrm{XM}+\dot{\varepsilon}
$$

Where $\mathrm{Y}=$ performance of the securities markets measured in terms of price index

$\mathrm{X}=$ Foreign exchange fluctuation (the average of the Kenya's top three exchange rates)

$\mathrm{M}=$ interest rates

$\mathrm{XM}=$ interaction between foreign exchange rates and interest rates

$\beta_{0}=$ constant

$\beta_{1}=$ main effect of $X$ on $Y$

$\beta_{2}=$ main effect of $\mathrm{M}$ on $\mathrm{Y}$

$\beta_{3}=$ moderating effect

In this regard, the study tested the interaction between foreign exchange rates and interest rates. Hierarchical regression analysis was used to test for moderation. Thus foreign exchange rates and interest rates were entered in step 1 of the hierarchical regression followed by the interaction variable entered in step 2 . The interaction variable was the product of the standardized variables for foreign exchange rates and interest rates. Standardization was found necessary to reduce threats of multicollinearity by reducing the size of correlations between foreign exchange rates and interest rates and their interaction. The change in $\mathrm{R}^{2}$ was then used to assess moderation. A significant change in $\mathrm{R}^{2}$ was adjudged to confirm moderation.

Results shown in Table 6 indicate that the $\mathrm{R}^{2}$ change of 0.085 was significant at the 0.05 level. The hypothesis that interest rates moderate the relationship between foreign exchange rates and performance of the securities markets was therefore not rejected.

Table 6. Results of the moderation Test

\begin{tabular}{|c|c|c|c|c|c|c|c|c|c|c|}
\hline \multirow[b]{2}{*}{ Model } & \multirow{3}{*}{$\begin{array}{c}\mathrm{R} \\
.427^{\mathrm{a}}\end{array}$} & \multirow{3}{*}{$\begin{array}{c}\text { R Square } \\
.182\end{array}$} & \multirow{3}{*}{$\begin{array}{c}\begin{array}{c}\text { Adjusted R } \\
\text { Square }\end{array} \\
.153\end{array}$} & \multirow{3}{*}{$\begin{array}{c}\text { Std. Error of the } \\
\text { Estimate }\end{array}$} & \multicolumn{5}{|c|}{ Change Statistics } & \multirow{3}{*}{ Durbin-Watson } \\
\hline & & & & & \multirow{2}{*}{$\begin{array}{c}\text { R Square } \\
\text { Change } \\
.182\end{array}$} & \multirow{2}{*}{$\begin{array}{c}\text { F Change } \\
6.250\end{array}$} & \multirow{2}{*}{$\frac{\mathrm{df} 1}{2}$} & \multirow{2}{*}{$\frac{\mathrm{df} 2}{56}$} & \multirow{2}{*}{\begin{tabular}{c|} 
Sig. F Change \\
.004
\end{tabular}} & \\
\hline 1 & & & & & & & & & & \\
\hline 2 & $.517^{\mathrm{b}}$ & .267 & .227 & 163.97344 & .085 & 6.361 & 1 & 55 & .015 & 1.678 \\
\hline \multicolumn{11}{|c|}{ a. Predictors: (Constant), Interest rates, Foreign exchange } \\
\hline \multicolumn{11}{|c|}{ b. Predictors: (Constant), Interest rates, Foreign exchange, Interaction } \\
\hline \multicolumn{11}{|c|}{ c. Dependent Variable: Price index } \\
\hline
\end{tabular}

Source: Research data, 2013 
Table 7. Results of the Moderation Coefficients

\begin{tabular}{|c|c|c|c|c|c|c|c|c|}
\hline & \multirow{2}{*}{ Model } & \multicolumn{2}{|c|}{ Unstandardized Coefficients } & \multirow{2}{*}{$\frac{\text { Standardized Coefficients }}{\text { Beta }}$} & \multirow{2}{*}{$\mathrm{t}$} & \multirow{2}{*}{ Sig. } & \multicolumn{2}{|c|}{ Collinearity Statistics } \\
\hline & & B & Std. Error & & & & Tolerance & VIF \\
\hline \multirow{4}{*}{2} & (Constant) & 314.977 & 47.886 & & 6.578 & .000 & & \\
\hline & Foreign exchange & -3.984 & 20.608 & -.035 & -.193 & .847 & .397 & 2.522 \\
\hline & Interest rates & -324.26 & 219.558 & -.193 & -1.477 & .145 & .778 & 1.285 \\
\hline & Interaction & -106.55 & 42.248 & -.425 & -2.522 & .015 & .470 & 2.129 \\
\hline
\end{tabular}

a. Dependent Variable: Price index

Source: Research data, 2013

Since the moderation effect was supported, the moderation model of interest rates on the relationship between foreign exchange rates fluctuation and performance of the securities markets was therefore tested. Results presented in Table 7 reveal that the interaction between interest rates and foreign exchange rate was a significant predictor of securities market performance $(\beta=-0.425$, $\mathrm{p}<0.05)$.

The moderation model was therefore estimated as:

Price index $=314.977-0.035$ foreign exchange rate -0.193 interest rates -0.425 foreign exchange*interest rates

\subsection{Discussions and Conclusion}

The findings in this study that interest rates moderate the relationship between foreign exchange fluctuation and performance of securities markets are consistent with findings by Reilly [28] and Schwert [32].

The results indicated that when interest rates are captured as an interaction with foreign exchange rates fluctuations, the overall influence is different with when interest rates and foreign exchange rates are considered as independent standalone variables

Using a 2-step hierarchical regression, the study established that there was a significant difference in $\mathrm{R}^{2}$ between the variables entered in step1 and those entered in step2. Consequently, interest rates were found to have a moderating effect on the relationship between performance of securities and foreign exchange rates fluctuation.

Based on the conclusion that interest rates have significant effect on the relationship between foreign exchange rate and the performance of Nairobi Securities Exchange market, the study recommends that the Central Bank of Kenya formulate favorable policies governing the regulation of interest rates as interest rates is at the core of the relationship between the performance of Nairobi securities exchange market and foreign exchange fluctuations. The regulation and management of interest rates will either encourage or discourage investment at the Nairobi securities exchange market which is one of the drivers of Kenya's economy.

\section{REFERENCES}

[1] Adjasi, C. K. D., \& Biekpe, B. N. (2005).Security Market Returns and Exchange Rate Dynamics in Selected African
Countries: A bivariate analysis. The African Finance Journal, July, Cape Town, South Africa.

[2] Adjasi, C. K. \& Yartey, C. A. (2007). Stock market development in sub-Saharan Africa: Critical issues and challenges. Washington D.C.: IMF African Department.

[3] Adjasi, C. K. D., Harvey, S. K., \& Agyapong, D. A. (2008).Effect of exchange rate volatility on the Ghana Stock Exchange African Journal of Accounting, Economics, Finance and Banking Research, 3( 3) 29-36

[4] Amare, T., \& Mohsin, M. (2000). Stock Prices and Exchange Rates in the Leading Asian Economies: Short versus Long Run Dynamics. Singapore Economic Review 45:2, 165-181.

[5] Benita, G., \& Lauterbach, B. (2004). Policy factors and exchange rate volatility: Panel data verses a specific country analysis, research unit. Foreign Exchange Activity Department, Bank of Israel, Jerusalem.

[6] Creswell, J. W. (1994). Research design, qualitative and quantitative approaches. Blackwell Publishing, Asia.

[7] Demirguc-Kunt, A. \& Ross, L. (1996). "Stock Market Development and Financial Intermediaries: Stylized Facts," The World Bank Economic Review, Vol. 10 (2), pp. 291- 232.

[8] Economic Survey Report, Kenya (2008)

[9] Golaka, C., \& Samanta, G. (2003). Relationship between exchange rate and stock prices in India - An Empirical Analysis. European Financial Management Journal

[10] Jyoti, P, G. \& Alain, C. (2000). The causality between interest rate, Exchange Rate and stock Price in emerging markets: The case of the Jakarta Stock Exchange. European Financial Management Journal.

[11] King, R. E. \& Levine, R. (1993a). "Financial Intermediation and Economic Development." in Financial Intermediation in the Construction of Europe. Editors: Colin

[12] King, R., \& Levine, R. (1993b). Finance and Growth: Schumpeter Might Be Right. Quarterly Journal of Economics, 108(3), pp. 717-37.

[13] Kolawole, S., \& Olalekan, M. S. (2010).Exchange rate volatility and the stock market: The Nigerian experience.

[14] Leader Investment Kenya, 2007.

[15] Lee, R. (1998). What is an exchange? The automation, management, and regulation of financial markets. New York: Oxford University Press Inc.

[16] Levine, R., \& Zervos, A. (1998). Stock Markets, Banks, and Economic Growth. American Economic Review, 88(3), pp. 
537-58.

[17] Levine, R., Loayza, N., \& Beck, T.(2000a). Financial intermediation and growth: Causality and causes. Journal of Monetary Economics, 46, 31-77.

[18] Levine, R., Loayza, N., \& Beck, T. (2000b). Finance and the sources of growth. Journal of Financial Economics, 58, 261300.

[19] Mendelson, M., \& Robbins, S. (1976). Investment analysis and security markets. New York: Basic Books, Inc.

[20] Mishra, K.A. (2004). Stock market and foreign exchange market in India. Are they related? South Asia Economic Journal, 5:2, Sage Publications, New Delhi.

[21] Mumcu, F. (2005). The effects of changes in foreign exchange rates on ISE-100 index www.aebrjournal.org/uploads/6/6/2/2/6622240/3._anlas.pdf

[22] Naliniprava, T. \& Meghalaya, S.(2011). Causal relationship between macro-economic indicators and stock market in India

[23] Ngugi, R. W., \& Njiru, R. (2005). Growth of the Nairobi stock exchange primary market, Nairobi: Kenya Institute of Public Policy Research Analysis.

[24] Ngugi, R.W., \& Kabubo, J.W. (1998). Financial sector reforms and interest rate liberalization: The Kenya experience, AERC Research Paper 72; African Economic Research Consortium, Nairobi.

[25] Otuke, J. (2006). Impact of central depository system on the performance of NSE-Unpublished MBA Dissertation, University of Nairobi.

[26] Pallegedara, A. \& Asankha, J.(2012). Dynamic relationships between stock market performance and short term interest rate,empirical evidence from Sri Lanka," MPRA Paper 40773, University Library of Munich, Germany. International Journal of Academic Research in Business and Social Sciences September 2012, Vol. 2, No. 9 ISSN: 2222-6990

[27] Phillips, B. C. (1987). Philosophy, science and social science inquiry: Contemporary methodological controversies of social sciences \& Related Applied Fields of Research. Elmsford, NY. Tergamamon.

[28] Reilly, F., \& Brown C. (1997). Investment analysis and portfolio management. New Jersey: Prentice Hall Inc.

[29] Robson, C. (1993). Real world research. A resource for social scientists and practitioner research. Oxford, Blackwell.

[30] Seetanah, B. (2008). 'Financial development and economic growth in an ARDL approach. Applied Economics Letter, 4(43), pp 43-50

[31] Schiffman, L. G. \& Kanuk, L. (2009). Consumer behaviour $6^{\text {th }}$ Ed. Boston Prentice Hall.

[32] Schwert, G. W., French, K. R. I., Robert F. (1990).Expected stock returns and volatility. Journal of Financial Economics, 19, 3-29.

[33] Smith, J. K. (1983). Quantitative versus qualitative research, an attempt to clarify the issue. Educational Research, 6-13.

[34] Tulin, A. (2012). The effects of changes in foreign exchange rates on ISE-100 index. Journal of Applied Economics and Business Research JAEBR, 2(1), 34-45.

[35] Zia, Q. \& Zaid, R. (2011). The Causality between stock market and foreign exchange market of Pakistan interdisciplinary Journal of Contemporary Research in Business Vol.3(5). 